\title{
Effect of parathyroid hormone-related protein on odontogenic differentiation in human dental pulp cells
}

\author{
Mi-Ra Kim ${ }^{1 \dagger}$, Sung-Hyeon Choi ${ }^{1 \dagger}$, Bin-Na Lee ${ }^{1}$, Kyung-San Min² and Yun-Chan Hwang ${ }^{1 *}$
}

\begin{abstract}
Background: Parathyroid hormone-related protein (PTHrP) plays an important role in many physiological processes, including bone regeneration. The function of PTHrP is similar to PTH. It promotes osteogenic differentiation in MC3T3-E1 cells. The aim of this study was to investigate whether PTHrP might have odontogenic differentiation ability in human dental pulp cells (hDPCs).

Methods: The viability of hDPCs after stimulation with PTHrP was measured. Real-time polymerase chain reaction and Western blot analysis were performed to evaluate the expression levels of odontogenic markers and activation of protein kinase B (PKB/AKT), extracellular signal-regulated kinase (ERK), c-Jun N-terminal kinase (JNK), and p38 mitogen-activated protein kinase (MAPK). To evaluate mineralized nodule formation, alkaline phosphatase (ALP) staining and alizarin red S staining were performed.

Results: PTHrP promoted odontogenic differentiation as evidenced by the formation of mineralized nodules, the induction of ALP activity, and the upregulation of odontogenic markers (dentin sialophosphoprotein and dentin matrix protein-1). The phosphorylation of AKT, ERK, JNK, and p38 was increased by PTHrP. However, an AKT inhibitor (LY294002), an ERK inhibitor (U0126), a JNK inhibitor (SP600125), and a p38 inhibitor (SB203580) inhibited the increase of mineralization induced by PTHrP.

Conclusion: The present study revealed that PTHrP could promote odontogenic differentiation and mineralization through activating the AKT, ERK, JNK, and p38 signaling pathways. These results provide novel insights into the odontogenic action of PTHrP.
\end{abstract}

Keywords: PTHrP, Odontogenic differentiation, Mineralization

\section{Background}

Dentin is a major component of teeth. It shows strong regenerative potential [1]. When infected dentin is removed, the pulp may be exposed. Regeneration therapy, such as direct pulp capping, can keep pulp viable and

\footnotetext{
* Correspondence: ychwang@chonnm.ac.kr

${ }^{+} \mathrm{Mi}$-Ra Kim and Sung-Hyeon Choi contributed equally to this work as first authors.

'Department of Conservative Dentistry, School of Dentistry, Dental Science Research Institute, Chonnam National University, Youngbong-ro 77, Buk-gu, Gwangju 61186, South Korea

Full list of author information is available at the end of the article
}

form a physical barrier. It could function as a biological seal between dental material and pulp tissue [2, 3]. Successful pulp capping is very important and is affected by several factors. Growth factors play a key role in cell survival, proliferation, and differentiation for the successful regeneration of pulp-dentin complexes $[3,4]$.

Dental pulp stem cells are clonogenic cells capable of both self-renewal and multiple lines of differentiation [5]. Dental pulp cells can differentiate into odontoblasts that act as precursor cells important for dentin formation $[6,7]$. Several studies have shown that biologically

(c) The Author(s). 2020 Open Access This article is licensed under a Creative Commons Attribution 4.0 International License, which permits use, sharing, adaptation, distribution and reproduction in any medium or format, as long as you give appropriate credit to the original author(s) and the source, provide a link to the Creative Commons licence, and indicate if changes were made. The images or other third party material in this article are included in the article's Creative Commons licence, unless indicated otherwise in a credit line to the material. If material is not included in the article's Creative Commons licence and your intended use is not permitted by statutory regulation or exceeds the permitted use, you will need to obtain permission directly from the copyright holder. To view a copy of this licence, visit http://creativecommons.org/licenses/by/4.0/ The Creative Commons Public Domain Dedication waiver (http://creativecommons.org/publicdomain/zero/1.0/) applies to the data made available in this article, unless otherwise stated in a credit line to the data. 
active components such as osteostatin can enhance the osteogenic differentiation and mineralization of osteoblastic cells that are responsible for new bone formation [8]. Similar to bone formation, osteostatin can lead to reparative dentin formation by inducing osteoblast-like human dental pulp stem cells (hDPCs) [9].

Parathyroid hormone-related protein (PTHrP) can induce bone formation. A previous study reported that the osteogenic differentiation of MC3T3-E1 cells could be promoted by the bone-forming ability of PTHrP at various concentrations [10]. PTHrP is a major contributor to hypercalcemia. It is similar to PTH structurally and functionally [11, 12]. It influences chondrocytic and osteogenic cell biology and plays an important role in bone remodeling, the regulation of fetal blood calcium, and many physiologic processes [13-15]. PTHrP can increase the expression levels of COL2A1 and Sox9, known to be involved in chondrogenic differentiation in chondrogenic medium in mesenchymal stem cells. It can significantly enhance cartilage formation and upregulate chondrocyte proliferation through cyclin-dependent kinase inhibition [16-18].

Previous studies have demonstrated that PTHrP 1141 and PTHrP 1-86 possess anabolic action, indicating that osteogenic differentiation could be promoted in MC3T3-E1 cells by assessing the osteogenic ability of PTHrP at varying concentrations [12, 19]. In contrast, PTHrP homozygous mutants caused abnormalities in endochondral bone growth with short ribs and malformed long bones [20, 21]. Several studies have shown that PTHrP activated signaling pathways, leading to the activation of several transcription factors that play important roles in signal transduction in osteoblasts [2224].

The odontogenic potential of PTHrP has not yet been reported. Therefore, the aim of this study was to investigate the underlying signaling mechanisms of PTHrPmediated odontogenic differentiation.

\section{Methods}

\section{Cell isolation and culture of hDPCs}

This study was approved by the Institutional Review Board of Chonnam National University Dental Hospital, Gwangju, Korea (IRB No. CNUDH-2016-009). Written informed consent was obtained from each patient included in this study. Extracted human third molars with pulp tissues were obtained from the Department of Oral Maxillofacial Surgery, Chonnam National University Dental Hospital. Tooth samples were removed aseptically, rinsed with Dulbecco's phosphate-buffered saline solution (DPBS, Welgene, Daegu, South Korea), and placed in $60 \mathrm{~mm}$ dishes. The cells were cultured in growth media (GM) consisting of $\alpha$-minimum essential medium ( $\alpha$-MEM, Gibco Invitrogen, Grand Island, NY,
USA) supplemented with $10 \%$ fetal bovine serum (FBS, Gibco Invitrogen) and $1 \%$ antibiotics $(100 \mathrm{U} / \mathrm{mL}$ penicillin and $100 \mathrm{mg} / \mathrm{mL}$ streptomycin, Gibco Invitrogen) in a humidified atmosphere of $5 \% \mathrm{CO}_{2}$ at $37^{\circ} \mathrm{C}$. For mineralization experiments, the cells were cultured in odontogenic induction medium (OM) containing $50 \mathrm{mg} /$ $\mathrm{mL}$ ascorbic acid (Sigma-Aldrich, St. Louis, MO, USA) and $10 \mathrm{mmol} / \mathrm{L} \beta$-glycerophosphate (Santa Cruz Biotechnology, Inc., Dallas, TX, USA). When the cells reached confluence, subcultures were performed and cells with passage numbers 3 to 4 were used for this study and rinsed with DPBS. The cells were detached with an appropriate quantity of trypsin solution (Gibco Invitrogen) for three minutes in a $\mathrm{CO}_{2}$ incubator in a humidified atmosphere of $5 \% \mathrm{CO}_{2}$ at $37^{\circ} \mathrm{C}$. The cell suspension was transferred to a tube and gently centrifuged at 800 RPM for five minutes. After removing the supernatant, the cell pellet was gently resuspended in GM consisting of $10 \% \alpha$-MEM. The density of the viable cells was determined by counting in a hemocytometer and the cells were seeded in wells or dishes in the following experiments.

\section{PTHrP treatment}

Recombinant human PTHrP (Sigma-Aldrich) was directly added at $1 \mathrm{nM}$ or $10 \mathrm{nM}$ to the OM. The cells were treated with PTHrP the next day after seeding and incubated with PTHrP for 3, 5, 7, or 14 days. The medium was changed with fresh medium containing PTHrP every two days.

\section{Cytotoxicity test}

HDPCs were seeded at a density of $1 \times 10^{4}$ cells per well in 96-well culture plates. After $24 \mathrm{~h}$ of culture, the cells were treated with PTHrP at different concentrations (1, 10 , and $100 \mathrm{nM}$ ) for $24 \mathrm{~h}$. After $24 \mathrm{~h}$ of culture, cell viability was analyzed by the WST-1 assay using an EZCytox Enhanced Cell Viability Assay Kit (Daeil Lab Service, Seoul, Korea). Briefly, $10 \mu \mathrm{L}$ of EZ-Cytox reagent was added to each well in the 96-well plate and incubated at $37^{\circ} \mathrm{C}$ for four hours. The absorbance was measured at a wavelength of $420 \mathrm{~nm}$ using a spectrophotometer (Thermo Scientific Multiskan GO, Waltham, MA, USA).

\section{RNA extraction and quantitative real-time polymerase} chain reaction assay

HDPCs were seeded at a density of $2 \times 10^{5}$ cells per well in 6-well culture plates with GM. After $24 \mathrm{~h}$ of culture, the cells were treated in OM with or without 1 and 10 nM PTHrP for three and five days. Total RNA was then extracted from the cells using Trizol reagent (Gibco Invitrogen) according to the manufacturer's recommended protocol. Complementary DNA (cDNA) was 
synthesized using a random primer (Promega Biotech, Piscataway, NJ, USA) and an AccessQuick ${ }^{\text {ma }}$ real-time polymerase chain reaction (RT-PCR) system (Promega, Madison, WI, USA). Quantitative RT-PCR was performed using a QuantiTect SYBR Green PCR Kit (Qiagen, Valencia, CA, USA) on a 72-well Rotor-Gene 6000 (Corbett Research, Sydney, Australia). The primer sequences used for PCR are listed in Table 1. The relative gene expression levels were analyzed using the $2^{-\Delta \Delta C t}$ method. To examine the effect of PTHrP, the same assay described above was performed for cells cultured in OM with or without PTHrP at 1 or $10 \mathrm{nM}$.

\section{Western blot analysis}

HDPCs were seeded at a density of $3 \times 10^{5}$ cells per dish on $60 \mathrm{~mm}$ cell culture dishes and cultured in OM with or without PTHrP at 1 or $10 \mathrm{nM}$. The medium was replaced with fresh medium every two days. The PTHrPinduced odontogenic protein expression and activation of protein kinase $\mathrm{B}(\mathrm{PKB} / \mathrm{AKT})$, extracellular signalregulated kinase (ERK), c-Jun $\mathrm{N}$-terminal kinases (JNK), and p38 mitogen-activated protein kinase (MAPK) were analyzed by Western blots. HDPCs were treated with or without PTHrP at 1 or $10 \mathrm{nM}$. The cells were washed twice with PBS and extracted with cell lysis buffer (Cell Signaling Technology, Beverly, MA, USA). Then cell lysates were then centrifuged at $13,000 \mathrm{rpm}$ for $10 \mathrm{~min}$. The supernatants were collected and protein concentrations were determined using a Lowry Protein Assay Reagent Kit (Bio-Rad Laboratories, Hercules, CA, USA). The proteins were subjected to $10 \%$ sodium dodecyl sulfate-polyacrylamide gel electrophoresis at $80 \mathrm{~V}$ for two hours and transferred to polyvinylidene difluoride membranes at $10 \mathrm{~V}$ overnight. After blocking with $5 \%$ non-fat dried skim milk in PBS containing 0.1\% Tween 20 (PBST) at room temperature for one hour, the membranes were incubated with anti-dentin sialophosphoprotein (DSPP) (1:2000; Thermo Fisher Scientific), antidentin matrix protein (DMP)-1 (1:2000; Abcam, Cambridge, UK), anti-ERK (1:2000; Cell Signaling Technology), and anti-phospho-ERK (1:2000; Cell Signaling Technology) at $4{ }^{\circ} \mathrm{C}$ overnight. After washing three times with PBST, the membranes were then incubated with horseradish peroxidase (HRP)-conjugated anti-rabbit

Table 1 List of primers used for real-time PCR

\begin{tabular}{ll}
\hline Gene & Sequences (5'-3') \\
\hline DSPP & Forward: GGG AAT ATT GAG GGC TGG AA \\
& Reverse: TCA TTG TGA CCT GCA TCG CC \\
DMP-1 & Forward: TGG TCC CAG CAG TGA GTC CA \\
& Reverse: TGT GTG CGA GCT GTC CTC CT \\
$\beta$-actin & Forward: CTC CTT AAT GTC ACG CAC GAT \\
& Reverse: CCT TGT AGC CAG GCC CAT TG \\
\hline
\end{tabular}

IgG secondary antibodies (1:10,000 Sigma-Aldrich) at room temperature for one hour. After washing with PBS five times, chemiluminescent HRP substrate (Millipore, Billerica, MA, USA) was used to visualize the protein signals with a Chemiluminescence Imaging System (Ezcapture; Atto, Tokyo, Japan).

\section{Alkaline phosphatase staining assay}

HDPCs were seeded at a density of $2 \times 10^{4}$ cells per well in 24-well culture plates and cultured in GM and OM with or without PTHrP at 1 or $10 \mathrm{nM}$ for seven days. Fresh GM and OM were replaced every two days. After seven days of exposure, the medium was removed. The cells were washed with PBS and fixed in 70\% ethanol for one hour, followed by rinsing with distilled water three times. The fixed cells were treated with $300 \mu \mathrm{L}$ alkaline phosphatase (ALP) staining reagent (1-step NBT/BCIP solution; Thermo Fisher Scientific) per well. After removing the staining reagent, a photograph was taken using an Officejet Pro L7580 scanner (Hewlett-Packard, Palo Alto, CA, USA). To quantitatively evaluate the staining results, the stain was treated with $10 \%$ cetylpyridinium chloride $(\mathrm{pH}=7.0)$ for $30 \mathrm{~min}$ at room temperature, followed by absorbance measurement at a wavelength of $562 \mathrm{~nm}$ using a spectrophotometer (Thermo Scientific Multiskan GO).

\section{Alizarin red staining assay}

HDPCs were seeded at a density of $2 \times 10^{4}$ cells per well in 24-well cell culture plates and cultured in GM and $\mathrm{OM}$ with or without PTHrP at 1 or $10 \mathrm{nM}$ for 14 days. After 14 days, the cells were fixed in $70 \%$ ethanol and stained with $2 \%$ alizarin red $\mathrm{S}$ staining reagent (LIFELINE Cell Tech, Frederick, MD, USA). The results were recorded using an Officejet Pro L7580 scanner. For quantitative analysis, $10 \%$ cetylpyridinium chloride $(\mathrm{pH}=$ 7.0) was added to each sample and the absorbance value was measured at a wavelength of $540 \mathrm{~nm}$ using a spectrophotometer (Thermo Scientific Multiskan GO).

\section{Statistical analysis}

Three independent experiments were performed. The results are expressed as means \pm standard deviation of the means. Statistical significance was determined by one-way analysis of variance. All statistical analyses were performed using SPSS 23.0 software program (SPSS, Chicago, IL, USA). Differences were considered statistically significant at $P<0.05$.

\section{Results}

Effects of PTHrP on cell viability of hDPCs

A WST-1 assay was performed to evaluate the cell viability of hDPCs treated with PTHrP at 1,10 , and 100 $\mathrm{nM}$. The cell viability was not significantly different 
between the untreated group and the groups treated with different concentrations of PTHrP (Fig. 1a).

\section{Effects of PTHrP on Odontogenic differentiation and mineralization in hDPCs}

Quantitative RT-PCR analyses were performed to investigate the effect of PTHrP on odontogenic differentiation in hDPCs. The DSPP and DMP-1 mRNA expression levels were gradually increased with increasing concentrations of PTHrP three and five days after treatment. DSPP mRNA levels were significantly increased in the group treated with $10 \mathrm{nM}$ PTHrP compared to the group not treated with PTHrP $\left({ }^{\text {sut }} P<0.01\right)$ (Fig. 1b).
DMP-1 mRNA levels were also significantly increased after treatment with PTHrP at concentration of 1 or 10 nM compared to the group not treated with PTHrP $\left(P<.05\right.$ and $\left.{ }^{* * * *} P<.001\right)$ (Fig. 1c).

Western blot analyses were performed to investigate the effect of PTHrP on the odontogenic differentiation in hDPCs. As shown in Fig. 1d, the protein levels of DSPP in the PTHrP-treated cells were higher than those in the no PTHrP group on days 3 and 5, although the difference was not statistically significant. The protein levels of DMP-1 were increased significantly in the group treated with $10 \mathrm{nM}$ PTHrP on day 5 and slightly increased on day 3 .
A

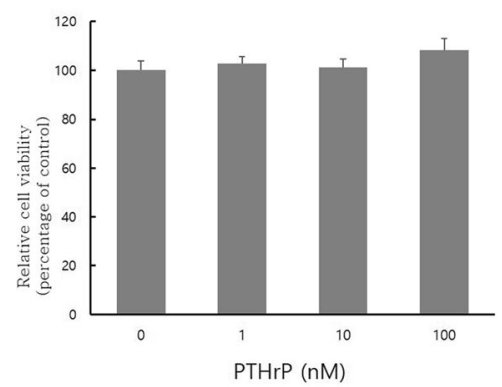

C

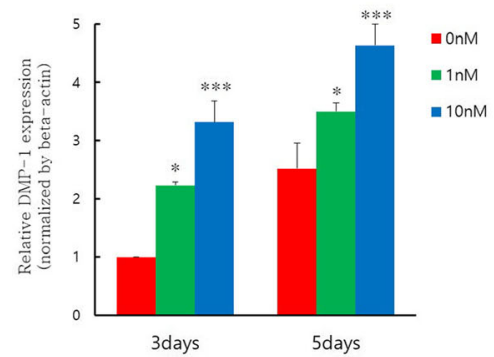

E

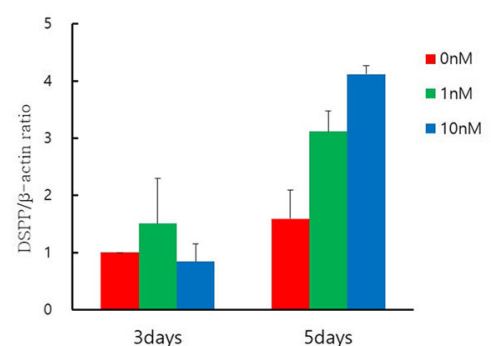

B

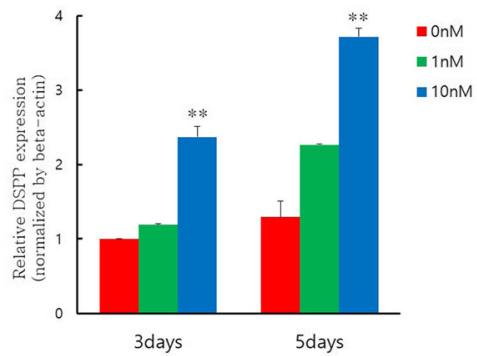

D

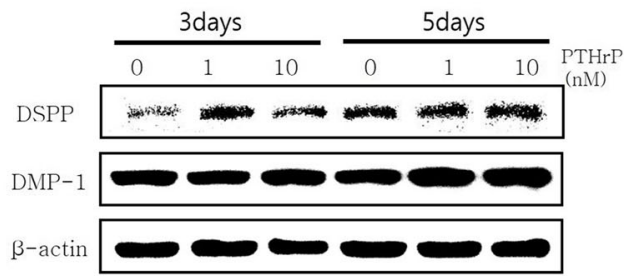

$\mathrm{F}$

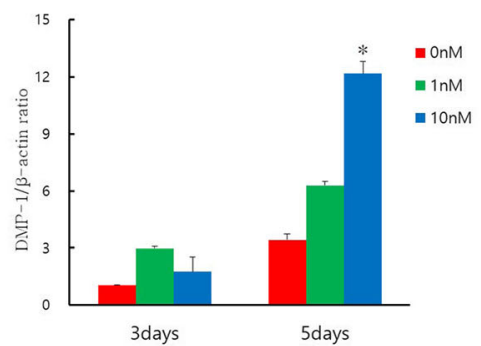

Fig. 1 a Results of water-soluble tetrazolium salt-1 assay for assessing the viabilities of hDPCs treated with PTHrP at different concentrations (1, 10 , and $100 \mathrm{nM})$. The effects of PTHrP at 1 and $10 \mathrm{nM}$ on mRNA expression levels of odontogenic markers were determined by quantitative reverse transcription-polymerase chain reaction. The expression levels of $\mathbf{b}$ DSPP and $\mathbf{c}$ DMP-1 in hDPCs Stimulated with PTHrP at 1 or 10 nM over different time periods were determined. $\mathbf{d}$ DSPP and DMP-1 protein levels were increased after treatment with $1 \mathrm{nM}$ or $10 \mathrm{nM}$ of PTHrP for three and five days compared to those in the control without PTHrP treatment. (E-F) Graphic representation of DMP-1 and DSPP protein levels. These graphs were normalized to data from cells not treated with PTHrP. * Statistically significant difference compared to the no PTHrP group ( $<<0.05)$, ${ }^{* *}$ Statistically significant difference compared to the no PTHrP group $(P<0.01)$. ${ }^{* * *}$ Statistically significant difference compared to the no PTHrP $\operatorname{group}(P<0.001)$ 
To verify the mineralization effect of PTHrP on hDPSCs, ALP staining and Alizarin red staining with or without 1 or $10 \mathrm{nM} \mathrm{PTHrP}$ treatment were performed. After seven days, ALP staining was significantly $\left({ }^{m a n} P<\right.$ 0.001) increased in all groups compared to that in the GM group. There was also a significant difference in ALP staining in the $1 \mathrm{nM}$ or $10 \mathrm{nM}$ PTHrP groups compared to the no PTHrP group $\left({ }^{\# \#} P<0.01\right.$ and $\left.{ }^{\# \#} P<0.001\right)$. After 14 days, treatment with 1 and $10 \mathrm{nM}$ PTHrP significantly enhanced calcium nodule deposition based on Alizarin red staining compared to the GM or no PTHrP groups $\left({ }^{\#} P<0.05,{ }^{\prime \prime m} P<0.01\right.$ and $\left.{ }^{m * * *} P<0.001\right)$ (Fig. 2$)$.

\section{Effects of PTHrP on AKT, ERK, JNK, and p38 signaling pathways}

To investigate the signaling pathways involved in the PTHrP-induced odontogenic differentiation of hDPCs, the phosphorylation of AKT, ERK, JNK, and p38 in hDPCs was assessed by Western blot analysis. The results showed that treatment with $10 \mathrm{nM}$ PTHrP increased the levels of p-AKT, p-ERK1/2, p-JNK, and pp38 five minutes after treatment. These increases were sustained $30 \mathrm{~min}$ or $60 \mathrm{~min}$ after treatment (Fig. 3a).

To further investigate the role of AKT, ERK, JNK, and p38 signaling in the odontogenic differentiation induced by PTHrP, cells were pretreated with or without $10 \mu \mathrm{M}$ LY294002 (AKT inhibitor; Cell Signaling Technology, \#9901), $10 \mu \mathrm{M}$ U0126 (ERK inhibitor; Cell Signaling Technology, \#9903), $10 \mu \mathrm{M}$ SP600125 (JNK inhibitor; Cell Signaling Technology, \#8177), or $10 \mu \mathrm{M}$ SB203580 (p38 inhibitor; Cell Signaling Technology, \#5633) for one hour, followed by treatment with $1 \mathrm{nM}$ PTHrP for seven or 14 days. LY294002, U0126, SP600125, and SB203580 also significantly ( $\left.{ }^{* * a t} P<0.001\right)$ decreased the ALP staining and mineralized nodule formation induced by PTHrP (Fig. 3)b-e.

\section{Discussion}

PTHrP is a paracrine regulator that plays an important role in bone growth and placental calcium transport
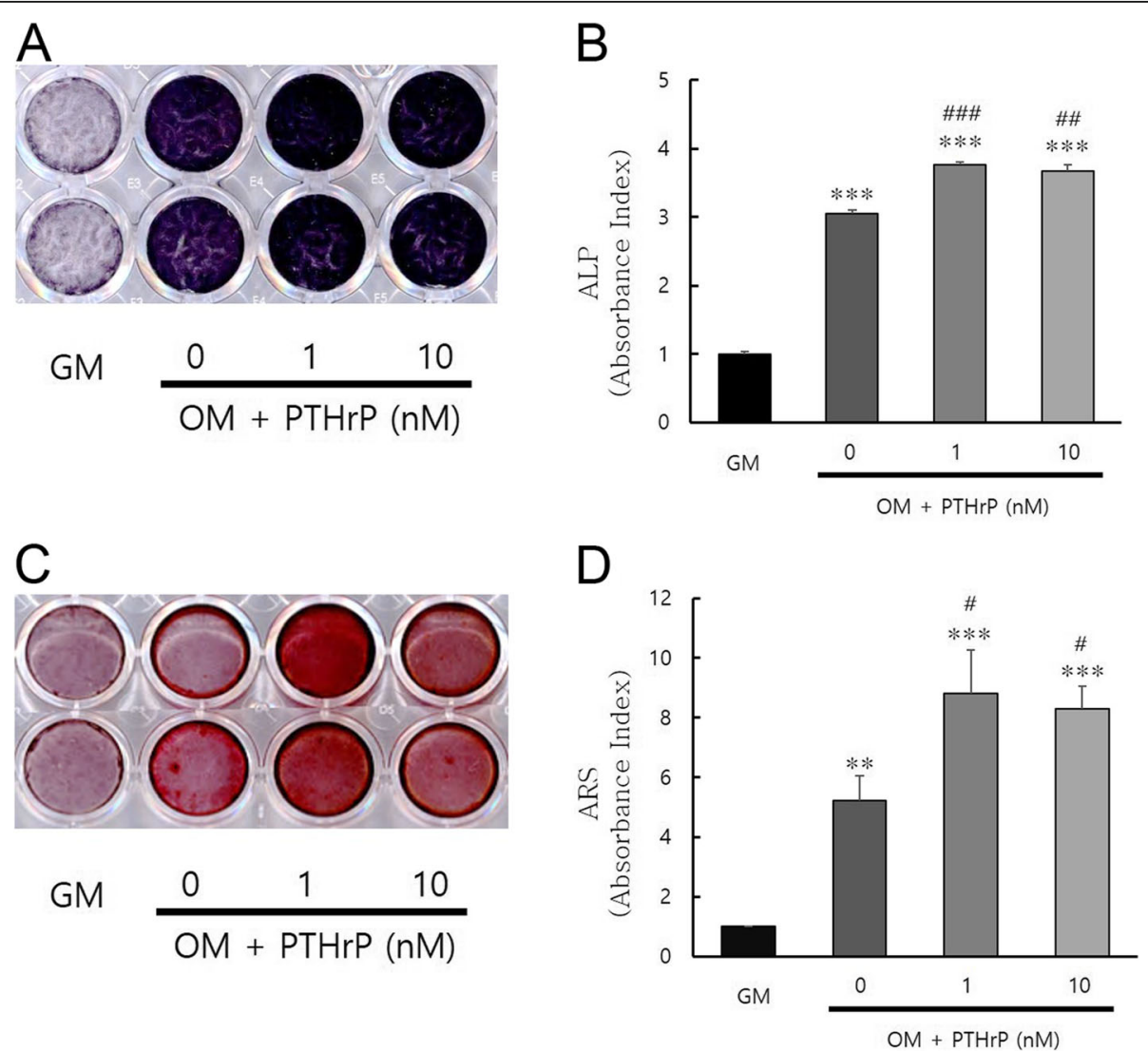

Fig. 2 Effect of PTHrP on mineralization in hDPCs. (a) Cells cultured with or without PTHrP at 1 or $10 \mathrm{nM}$ for seven days. ALP activity was evaluated by ALP staining. (b) Quantification of ALP staining. ALP staining was increased after PTHrP treatment for seven days compared to the GM control without PTHrP treatment. (c) Cells cultured with or without PTHrP at 1 or $10 \mathrm{nM}$ for 14 days. Calcium nodule deposition was evaluated by Alizarin red S staining. (d) Quantification of Alizarin red S staining. Mineralized nodule formation was significantly increased after PTHrP treatment compared to the GM and the OM groups without PTHrP treatment. The graphs were normalized to GM $\left({ }^{*} P<0.05\right.$, ${ }^{* *} P<0.01$, and ${ }^{* * *} P<0.001$ compared to GM group; ${ }^{\#} P<0.05$, ${ }^{\# \#} P<0.01$, and ${ }^{\# \# \#} P<0.001$ compared to the OM group without PTHrP treatment) 


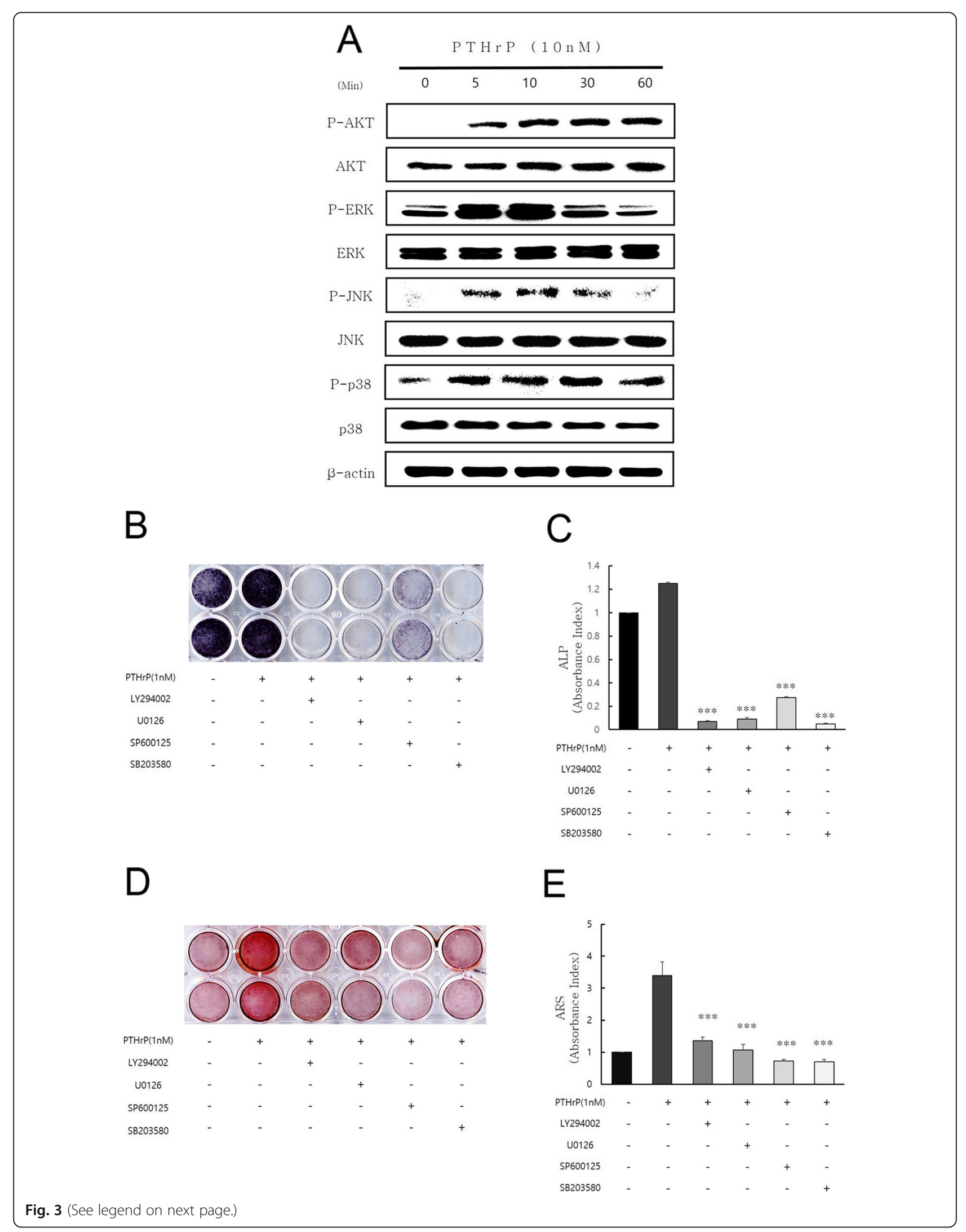


(See figure on previous page.)

Fig. 3 Effects of PTHrP on AKT, ERK, and JNK signaling pathways in hDPCs. (a) Effects of PTHrP on AKT, ERK, and JNK phosphorylation were assessed by Western blot analysis. Phosphorylation levels of AKT, ERK, and JNK were increased by PTHrP. (b-e) Effects of PTHrP and LY294002, U0126, and SP600125 on ALP staining and alizarin red S staining. The cells were pretreated with or without $10 \mu \mathrm{M}$ LY294002, $10 \mu \mathrm{M} \cup 0126$, or 10 MM SP600125 for one hour after treatment with $1 \mathrm{nM}$ PTHrP. ALP staining $(\mathbf{b}, \mathbf{c})$ and alizarin red S staining $(\mathbf{d}, \mathbf{e})$ are shown. LY294002, U1026, and SP600125 significantly decreased PTHrP-induced ALP staining and mineralization $\left({ }^{* * *} P<0.001\right.$ compared with the group treated with

$1 \mathrm{nM}$ PTHrP)

[25]. It has physiological anabolic action in bone [26]. In vitro studies have suggested that PTHrP can modulate chondrocyte proliferation and differentiation partially by activating Gli3 [27]. PTHrP is also an important signal in osteoclast activation. It was shown to be essential in the process of tooth eruption in PTHrP-knockout mice rescued by a procollagen II-driven transgene. It plays an important role in cell proliferation and differentiation through PTH1R [23, 28].

PTHrP can affect proliferation and differentiation in osteoblasts. The PKC-dependent activation of the MAPK signaling pathway in rat mesenchymal progenitor cells was shown to stimulate osteogenic cell proliferation [29, 30]. PTHrP can increase the secretion of mineralization, ALP Activity, and osteocalcin, thereby activating peptides and protein and increasing cell proliferation and bone formation $[10,19]$. The effect of PTHrP on odontogenic differentiation has not been reported. However, the odontogenic potential of osteostatin [fragment of PTHrP (107-111)] was demonstrated in a previous study [31]. Therefore, this study is the first to show the odontogenic potential of PTHrP in hDPCs. The reason for using hDPCs in this study was that most of the studies in systematic reviews reported positive results when hDPCs were used for hard tissue engineering. HDPCs have a demonstrated ability to proliferate even faster than bone marrow cells, to be homogenous, and possess an excellent capability to differentiate toward numerous cell lines [5, 7].

Cell viability was measured after treatment with PTHrP at concentrations of $1 \mathrm{nM}, 10 \mathrm{nM}$, and $100 \mathrm{nM}$ using the WST-1 assay. Previous studies have reported that when PTHrP was administered in excess, it affected dentin thickness and crevice formation [32]. Therefore, $1 \mathrm{nM}$ and $10 \mathrm{nM}$ of PTHrP were used in the present study. This result was consistent with the results of Ge $\mathrm{X}$ et al. [33].

The cell incubation times was determined based on a previous study [31]. The present study showed that different concentrations of PTHrP can induce odontogenic differentiation evidenced by the induction of ALP activity and the formation of mineralized nodules, as well as the upregulation of odontogenic markers. DMP1 and DSPP in odontoblasts are positive regulators of hard tissue mineralization with essential roles in the mineralization of dentin [34, 35]. Therefore, they were used as differentiation markers in the present study. Because there is a relationship between osteogenesis and odontogenesis [36], osteogenic differentiation markers, such as runt-related transcription factor 2 (Runx2), osterix (OSX), and osteocalcin (OCN) are also good markers for the effects of PTHrP on mineralization and have been studied in previous studies. PTHrP increased collagen type 1 (Col-1), osteopontin (OPN), OCN, and OSX mRNA and protein expression [10, 19]. As shown in Fig. 1, the relative mRNA levels of DSPP and DMP-1 were significantly higher in cells treated with PTHrP at 1 or $10 \mathrm{nM}$ than those in cells not treated with PTHrP. The protein expression levels of DSPP and DMP-1 were increased in PTHrP-treated cells compared to the OM group without PTHrP treatment. The proteins were also significantly increased in the group treated with PTHrP at $10 \mathrm{nM}$ after five days. In addition, as shown in Fig. 2, ALP activity and mineralized nodules were significantly increased in the PTHrP-treated group compared to the GM and no PTHrP groups. These results are consistent with the results of a study on the PTH effects on the osteo/odontogenic differentiation of DPCs [33]. These results suggest that PTHrP may have clinical benefit in pulp-dentin complex regeneration.

MAPK cascades have been shown to play an important role in the transduction of extracellular signals to cellular responses, including cellular proliferation and differentiation in mammalian cells. It has been reported that $\mathrm{PTHrP} / \mathrm{PTH}$ treatment in proliferating osteoblasts can promote cell growth and that MAPKs play an important role in the effect of PTH and PTHrP on osteoblasts [30, 37, 38].

Tang et al. [39] reported that AKT and JNK were activated when apelin stimulated the proliferation of mouse osteoblastic MC3T3-E1 cells and that cell proliferation was inhibited by inhibitors of AKT and JNK. Another study reported that Runx2 increased P13K-AKT protein levels through the positive feedback loop of Runx2 and P13K-AKT. P13K-AKT signaling plays an important role in DNA binding and transcriptional activation of Runx2. Thus, osteoblast and chondrocyte differentiation and migration are connected. The role of AKT signaling in cell proliferation and differentiation has also been confirmed [40]. However, reports on PTHrP-related AKT signaling are insufficient.

This study investigated whether MAPK signaling and AKT signaling could affect PTHrP-mediated 
odontogenic differentiation. The inhibitor itself could have an endogenous effect to attenuate osteogenic differentiation. However, because the aim of this study was to investigate the underlying signaling mechanisms of PTHrP-mediated odontogenic differentiation, no inhibitor-alone group was included in the experimental conditions, based on previous studies [31, 41, 42]. The doses selected in the chemical inhibitor experiments were determined based on a previous study [41]. As shown in Fig. 3, the results showed that PTHrP increased the phosphorylation levels of AKT, ERK, JNK, and p38. The AKT inhibitor LY294002, ERK inhibitor U0126, JNK inhibitor SP600125, and p38 inhibitor SB203580 all inhibited the increase in ALP staining and mineralized nodule formation induced by PTHrP. These results suggest that PTHrP may be involved in odontogenic differentiation through the AKT, ERK, JNK, and p38 signaling pathways. However, further studies are needed to confirm the precise signaling mechanism involved in the PTHrP-induced odontogenic differentiation of hDPCs.

\section{Conclusion}

In conclusion, this study demonstrated that PTHrP could promote odontogenic differentiation and mineralization in hDPCs by activating the AKT, ERK, JNK, and p38 signaling pathways. Therefore, PTHrP might be clinically useful for inducing dentin formation.

\section{Supplementary information}

Supplementary information accompanies this paper at https://doi.org/10. 1186/s12903-020-01085-8.

\section{Additional file 1.}

Additional file 2.

\section{Abbreviations}

PTHrP: Parathyroid hormone-related protein; ALP: Alkaline phosphatase; DMP: Dentin matrix protein; DSPP: Dentin sialophosphoprotein; ERK: Extracellular signal-regulated kinase; FBS: Fetal bovine serum; GM: Growth media; hDPC: Human dental pulp cell; HRP: Horseradish peroxidase; IRB: Institutional review board; JNK: C-Jun N-terminal kinase: MAPK: Mitogen-activated protein kinases; MEM: Minimum essential medium; OM: Odontogenic induction media; PBS: Phosphate-buffered saline: WST: Water-soluble tetrazolium

\section{Acknowledgments}

Not applicable.

\section{Authors' contributions}

Conception and design of the study: MRK, BNL, and YCH. Performing most of the experiments: MRK. Acquisition and interpretation of the data: SHC, $\mathrm{KSM}$, and YCH. Statistical analysis of the data: SHC. Drafting of the manuscript: SHC, BNL, KSM, and YCH. Revising of the manuscript: SHC. All authors read and approved the final manuscript for publication.

\section{Funding}

This study was financially supported by a grant (CRI 18039-1) from Chonnam National University Hospital Biomedical Research Institute and a National Research Foundation of Korea (NRF) grant funded by the Korean government (No. 2016 R1D1A1B03930816). The funding bodies had no role in the design, collection, analysis, interpretation of data, or writing of the manuscript.

\section{Availability of data and materials}

The datasets generated or analyzed during the current study are available from the corresponding author upon reasonable request.

\section{Ethics approval and consent to participate}

All procedures were conducted with written informed consent, and the experimental protocol was approved by the Committee of Ethics of the Chonnam National University Dental Hospital (IRB\#: CNUDH-2016-009).

\section{Consent for publication}

Not applicable.

\section{Competing interests}

The authors declare that they have no competing interests.

\section{Author details}

'Department of Conservative Dentistry, School of Dentistry, Dental Science Research Institute, Chonnam National University, Youngbong-ro 77, Buk-gu, Gwangju 61186, South Korea. ${ }^{2}$ Department of Conservative Dentistry, School of Dentistry, Jeonbuk National University, 567 Baekje-daero, Deokjin-gu, Jeonju 54896, South Korea.

Received: 1 May 2019 Accepted: 25 March 2020

Published online: 10 April 2020

\section{References}

1. Chae Y, Yang M, Kim J. Release of TGF- $\beta 1$ into root canals with various final irrigants in regenerative endodontics: an in vitro analysis. Int Endod J. 2018; 51:1389-97.

2. Leye Benoist F, Gaye Ndiaye F, Kane AW, Benoist HM, Farge P. Evaluation of mineral trioxide aggregate (MTA) versus calcium hydroxide cement (Dycal ${ }^{\circledR}$ ) in the formation of a dentine bridge: a randomised controlled trial. Int Dent J. 2012;62:33-9.

3. Phung S, Lee C, Hong C, Song M, Yi J, Stevenson R, et al. Effects of bioactive compounds on odontogenic differentiation and mineralization. J Dent Res. 2017;96:107-15.

4. Smith A, Scheven B, Takahashi Y, Ferracane J, Shelton R, Cooper P. Dentine as a bioactive extracellular matrix. Arch Oral Biol. 2012:57:109-21.

5. Cristaldi M, Mauceri R, Tomasello L, Pizzo G, Pizzolanti G, Giordano C, et al. Dental pulp stem cells for bone tissue engineering: a review of the current literature and a look to the future. Regen Med. 2018;13:207-18.

6. Liu Z, Chen T, Han Q, Chen M, You J, Fang F, et al. HDAC inhibitor LMK-235 promotes the odontoblast differentiation of dental pulp cells. Mol Med Rep. 2018:17:1445-52.

7. Leyendecker Junior A, Gomes Pinheiro CC, Lazzaretti Fernandes T, Franco $\mathrm{BD}$. The use of human dental pulp stem cells for in vivo bone tissue engineering: a systematic review. J Tissue Eng. 2018;9:1-18.

8. Lozano D, Fernández-de-Castro L, Portal-Núnez S, López-Herradón A, Dapía S, Gómez-Barrena E, Esbrit P. The C-terminal fragment of parathyroid hormone-related peptide promotes bone formation in diabetic mice with low-turnover osteopaenia. Br J Pharmacol. 2011:162:1424-38.

9. Goldberg M. Pulp healing and regeneration: more questions than answers. Adv Dent Res. 2011;23:270-4.

10. Wang J, Li J, Yang L, Zhou Y, Wang Y. Dose-dependence of PTH-related peptide-1 on the osteogenic induction of MC3T3-E1 cells in vitro. Medicine (Baltimore). 2017;96:e6637-43.

11. Martin TJ, Suva LJ. Parathyroid hormone-related protein in hypercalcaemia of malignancy. Clin Endocrinol. 1989;31:631-48.

12. Strewler GJ, Stern P, Jacobs JW, Eveloff J, Klein RF, Leung SC, et al. Parathyroid hormonelike protein from human renal carcinoma cells. Structural and functional homology with parathyroid hormone. J Clin Invest. 1987:80:1803-7.

13. Karaplis AC, Vautour L. Parathyroid hormone-related peptide and the parathyroid hormone/parathyroid hormone-related peptide receptor in skeletal development. Curr Opin Nephrol Hypertens. 1997;6:308-13.

14. Kovacs CS, Lanske B, Hunzelman JL, Guo J, Karaplis AC, Kronenberg HM. Parathyroid hormone-related peptide (PTHrP) regulates fetal-placental 
calcium transport through a receptor distinct from the PTH/PTHrP receptor. Proc Natl Acad Sci U S A. 1996;93:15233-8.

15. Karaplis AC, Goltzman D. PTH and PTHrP effects on the skeleton. Rev Endocr Metab Disord. 2000;1:331-41.

16. Lefebvre V, Huang W, Harley VR, Goodfellow PN, De Crombrugghe B. SOX9 is a potent activator of the chondrocyte-specific enhancer of the pro alpha1 (II) collagen gene. Mol Cell Biol. 1997;17:2336-46.

17. Kim YJ, Kim HJ, Im GI. PTHrP promotes chondrogenesis and suppresses hypertrophy from both bone marrow-derived and adipose tissue-derived MSCs. Biochem Biophys Res Commun. 2008;373:104-8.

18. MacLean HE, Guo J, Knight MC, Zhang P, Cobrinik D, Kronenberg HM. The cyclin-dependent kinase inhibitor p57 Kip2 mediates proliferative actions of PTHrP in chondrocytes. J Clin Invest. 2004;113:1334-43.

19. Hildreth BE III, Werbeck JL, Thudi NK, Deng X, Rosol TJ, Toribio RE. PTHrP 1141 and 1-86 increase in vitro bone formation. J Surg Res. 2010;162:e9-17.

20. Karaplis AC, Luz A, Glowacki J, Bronson RT, Tybulewicz V, Kronenberg HM, et al. Lethal skeletal dysplasia from targeted disruption of the parathyroid hormone-related peptide gene. Genes Dev. 1994;8:277-89.

21. Philbrick WM, Dreyer BE, Nakchbandi IA, Karaplis AC. Parathyroid hormonerelated protein is required for tooth eruption. Proc Natl Acad Sci U S A. 1998;95:11846-51.

22. Swarthout JT, D'Alonzo RC, Selvamurugan N, Partridge NC. Parathyroid hormone-dependent signaling pathways regulating genes in bone cells. Gene. 2002;282:1-17.

23. Abou-Samra AB, Jüppner H, Force T, Freeman MW, Kong XF, Schipani E, et al. Expression cloning of a common receptor for parathyroid hormone and parathyroid hormone-related peptide from rat osteoblast-like cells: a single receptor stimulates intracellular accumulation of both CAMP and inositol trisphosphates and increases intracellular free calcium. Proc Natl Acad Sci U S A. 1992;89:2732-6.

24. Fukayama S, Schipani E, Jüppner H, Lanske B, Kronenberg HM, Abou-Samra $A B$, et al. Role of protein kinase-a in homologous down-regulation of parathyroid hormone (PTH)/PTH-related peptide receptor messenger ribonucleic acid in human osteoblast-like SaOS-2 cells. Endocrinology. 1994; 134:1851-8.

25. Martin TJ, Moseley JM, Williams ED. Parathyroid hormone-related protein: hormone and cytokine. J Endocrinol. 1997;154:S23-37.

26. Miao D, Li J, Xue Y, Su H, Karaplis AC, Goltzman D. Parathyroid hormonerelated peptide is required for increased trabecular bone volume in parathyroid hormone-null mice. Endocrinology. 2004;145:3554-62

27. Mau E, Whetstone H, Yu C, Hopyan S, Wunder JS, Alman BA. PTHrP regulates growth plate chondrocyte differentiation and proliferation in a Gli3 dependent manner utilizing hedgehog ligand dependent and independent mechanisms. Dev Biol. 2007;305:28-39.

28. Potts JT Jr, Jüppner H. Parathyroid Hormone and Parathyroid Hormone-Related Peptide in Calcium Homeostasis, Bone Metabolism, and Bone Development: The Proteins, Their Genes, and Receptors. In: Metabolic bone disease and clinically related disorders. 3rd ed. Academic press; 1998. p. $51-94$..

29. Miao D, Tong XK, Chan GK, Panda D, McPherson PS, Goltzman D. Parathyroid hormone-related peptide stimulates osteogenic cell proliferation through protein kinase C activation of the Ras/mitogenactivated protein kinase signaling pathway. J Biol Chem. 2001;276:32204-13.

30. Datta NS, Abou-Samra AB. PTH and PTHrP signaling in osteoblasts. Cell Signal. 2009;21:1245-54.

31. Han JW, Lee BN, Kim SM, Koh JT, Min KS, Hwang YC. Odontogenic potential of parathyroid hormone-related protein (107-111) alone or in combination with mineral trioxide aggregate in human dental pulp cells. J Endod. 2017; 43:2054-60.

32. Kato A, Suzuki M, Karasawa Y, Sugimoto T, Doi K. Histopathological study on the PTHrP-induced incisor lesions in rats. Toxicol Pathol. 2003;31:480-5.

33. Ge X, Li Z, Jing S, Wang Y, Li N, Lu J, et al. Parathyroid hormone enhances the osteo/odontogenic differentiation of dental pulp stem cells via ERK and P38 MAPK pathways. J Cell Physiol. 2020;235:1209-21.

34. D'souza R, Cavender A, Sunavala G, Alvarez J, Ohshima T, Kulkarni A, MacDougall M. Gene expression patterns of murine dentin matrix protein 1 (Dmp1) and dentin sialophosphoprotein (DSPP) suggest distinct developmental functions in vivo. J Bone Miner Res. 1997;12:2040-9.

35. Ono N, Nakashima K, Schipani E, Hayata T, Ezura Y, Soma K, et al. Constitutively active PTH/PTHrP receptor specifically expressed in osteoblasts enhances bone formation induced by bone marrow ablation. J Cell Physiol. 2012;227:408-15.

36. Chen S, Gluhak-Heinrich J, Wang Y, Wu Y, Chuang H, Chen L, et al. Runx2, osX, and dspp in tooth development. J Dent Res. 2009;88:904-9.

37. Zhang W, Liu HT. MAPK signal pathways in the regulation of cell proliferation in mammalian cells. Cell Res. 2002;12:9-18.

38. Datta NS, Pettway GJ, Chen C, Koh AJ, McCauley LK. Cyclin D1 as a target for the proliferative effects of PTH and PTHrP in early osteoblastic cells. J Bone Miner Res. 2007;22:951-64.

39. Tang SY, Xie H, Yuan LQ, Luo XH, Huang J, Cui RR, et al. Apelin stimulates proliferation and suppresses apoptosis of mouse osteoblastic cell line MC3T3E1 via JNK and PI3-K/Akt signaling pathways. Peptides. 2007;28:708-18.

40. Fujita T, Azuma Y, Fukuyama R, Hattori Y, Yoshida C, Koida M, et al. Runx2 induces osteoblast and chondrocyte differentiation and enhances their migration by coupling with PI3K-Akt signaling. J Cell Biol. 2004;166:85-95.

41. Ngo VA, Jung JY, Koh JT, Oh WM, Hwang YC, Lee BN. Leptin induces odontogenic differentiation and angiogenesis in human dental pulp cells via activation of the mitogen-activated protein kinase signaling pathway. J Endod. 2018:44:585-91.

42. Luo Z, Kohli MR, Yu Q, Kim S, Qu T, He W. Biodentine induces human dental pulp stem cell differentiation through mitogen-activated protein kinase and calcium-/calmodulin-dependent protein kinase II pathways. J Endod. 2014;40:937-42.

\section{Publisher's Note}

Springer Nature remains neutral with regard to jurisdictional claims in published maps and institutional affiliations.
Ready to submit your research? Choose BMC and benefit from:

- fast, convenient online submission

- thorough peer review by experienced researchers in your field

- rapid publication on acceptance

- support for research data, including large and complex data types

- gold Open Access which fosters wider collaboration and increased citations

- maximum visibility for your research: over $100 \mathrm{M}$ website views per year

At BMC, research is always in progress.

Learn more biomedcentral.com/submissions 